\title{
Nic o nas bez nas? Zaangażowanie ruchu osób z niepełnosprawnościami w monitoring wdrażania Konwencji ONZ o prawach osób niepełnosprawnych w Polsce. Studium przypadku
}

\begin{abstract}
Streszczenie
Artykuł 33 ratyfikowanej w 2012 r. przez Polskę Konwencji ONZ o prawach osób niepełnosprawnych (KPON) wskazuje konieczność prowadzenia działań monitorujących jej wdrażanie przez społeczeństwo obywatelskie, w tym w szczególności organizacje zrzeszające osoby z niepełnosprawnościami. Faktyczna reprezentacja i wpływ środowiska osób z niepełnosprawnościami w myśl zasady „nic o nas bez nas” jest przedmiotem szczególnego zainteresowania Komitetu ONZ o prawach osób niepełnosprawnych, który przygotował komentarz generalny do art. 33 poświęcony tej sprawie. W artykule przeanalizowany został sposób prowadzenia monitoringu KPON w Polsce i włączenie $\mathrm{w}$ ten proces osób $\mathrm{z}$ różnymi niepełnosprawnościami w kontekście wymagań określonych przez Komitet ONZ. W Polsce monitoring KPON prowadzony jest w dużej mierze przez duże organizacje pozarządowe i grono ekspertów, co ma swoje konsekwencje. Z działań monitoringowych i rzeczniczych praktycznie wykluczone są grupy osób z niepełnosprawnościami narażonych na wielokrotne wykluczenie i dyskryminację, a więc w szczególnie trudnej sytuacji.
\end{abstract}

Słowa kluczowe: osoby z niepełnosprawnościami, Konwencja o prawach osób niepełnosprawnych, monitoring, reprezentacja

1 Szkoła Główna Handlowa w Warszawie, Kolegium Ekonomiczno-Społeczne. 


\title{
Nothing about us without us? Involvement of the movement of persons with disabilities in monitoring of the implementation of the UN Convention on the Rights of Persons with Disabilities in Poland: a case study
}

\begin{abstract}
Article 33 of the UN Convention on the Rights of Persons with Disabilities (ratified by Poland in 2012) establishes that civil society, in particular persons with disabilities and their representative organizations, shall be involved and participate fully in the monitoring process. Their real representation and power were a subject to scrutiny by the UN Committee on the Convention on the Rights of Persons with Disabilities (CRPD), which prepared a general comment to article 33. In this paper, I analyse the monitoring of the Convention in Poland and ways in which persons with disabilities and their representative organizations have been involved in the process. In Poland the Convention is monitored mainly by experts and big NGOs, not without reasons and consequences. Persons with disabilities who are subject to discrimination and multiple exclusion, and therefore are in a particularly bad situation, are rarely involved in the monitoring and advocacy.
\end{abstract}

Keywords: persons with disabilities, Convention on the rights of Persons with Disabilities, monitoring, advocacy

W 2012 r. Polska ratyfikowała Konwencję ONZ o prawach osób niepełnosprawnych (KPON), a tym samym zobowiązała się do przestrzegania jej zapisów. Celem KPON jest „popieranie, ochrona i zapewnienie pełnego i równego korzystania ze wszystkich praw człowieka i podstawowych wolności przez wszystkie osoby niepełnosprawne oraz popieranie poszanowania ich przyrodzonej godności” (ONZ, 2006).

Konwencja to traktat na wielu poziomach przełomowy oraz wielkie osiągnięcie w dziedzinie zapewnienia i ochrony praw osób z niepełnosprawnościami - nie tylko wypełnia lukę w międzynarodowym prawie, wskazując na szczególną sytuację osób z niepełnosprawnościami, ale przede wszystkim podkreśla, że prawa osób tej grupy jako prawa człowieka są niezbywalne i kompleksowe. Nie ma drugiej Konwencji, która podpisana została przez tak wiele państw, ani drugiego dokumentu, który w tak istotny sposób wpłynął na sytuację osób niepełnosprawnych na całym świecie (De Beco, 2011).

Jednocześnie KPON wprowadził rewolucyjną zmianę w myśleniu o niepełnosprawności, przechodząc z medycznego (skupionego na leczeniu i rehabilitacji) do społecznego modelu postrzegania niepełnosprawności, skoncentrowanego 
na niwelowaniu barier w otoczeniu i rozpoznającego osoby z niepełnosprawnościami jako równoprawnych obywateli (m.in. De Beco, 2011; Barnes, 2014). Taka percepcja niepełnosprawności nie tylko zmienia rozumienie, czym są prawa osób niepełnosprawnych, ale także $\mathrm{w}$ istotny sposób wpływa na zadania państwa związane $\mathrm{z}$ ich realizacją. Warto odnotować, że w ostatnich latach wśród osób współtworzących KPON dominuje przekonanie, że model społeczny nie zapewnia wystarczającego zrozumienia, na czym mają polegać ochrona i realizacja praw osób z niepełnosprawnościami i że docelowy powinien być jeszcze szerszy model odwołujący się bezpośrednio do praw człowieka (Degener, 2016).

W Konwencję wpisany jest także mechanizm monitoringu jej wdrażania przez poszczególne państwa. W artykule 33 opisywanego dokumentu czytamy, że państwa strony powinny zarówno uruchomić punkt kontaktowy (focal point), krajowy mechanizm koordynujący, jak i wskazać niezależną instytucję ochrony praw człowieka, która odpowiedzialna będzie za monitoring wdrażania Konwencji. ONZ podkreśla także, że kluczową rolę przy prowadzeniu działań monitoringowych ma aktywny udział społeczeństwa obywatelskiego, w tym przede wszystkim włączenie organizacji osób z niepełnosprawnościami (DPO’s) i organizacji działających na ich rzecz.

Monitoring jest dużym wyzwaniem i napotyka bariery, które wpływają na jakość prowadzonych działań. Szczególną trudność sprawia faktyczne i jak najpełniejsze włączenie w ten proces środowiska osób z niepełnosprawnościami.

W niniejszym artykule podejmuję próbę analizy włączenia społeczeństwa obywatelskiego w działania związane z monitoringiem wdrażania KPON w Polsce, opisuję, jakie trudności są z nim związane i czy są grupy osób niepełnosprawnych, które de facto są z tych działań wykluczone.

Warto podkreślić, że artykuł napisany jest zarówno na podstawie literatury przedmiotu, jak i osobistych doświadczeń autorki związanych z zaangażowaniem w ruch na rzecz praw osób z niepełnosprawnościami z perspektywy sojuszniczej (pełnosprawnej działaczki).

Sformułowanie „osoby z niepełnosprawnościami” zamiast „osoby niepełnosprawne", mimo że niezgodne z pojęciem funkcjonującym w polskim prawie, używane jest celowo i wynika z przyjętego przez autorkę społecznego paradygmatu postrzegania niepełnosprawności jako jednej z cech definiujących osobę. Podejście to jest zgodne z Konwencją ONZ o prawach osób niepełnosprawnych i zostało uznane za obowiązujące w Polsce m.in. w opracowaniach Rzecznika Praw Obywatelskich (Kubicki, 2017). 


\section{Nic o nas bez nas - wytyczne Organizacji Narodów Zjednoczonych dotyczące prowadzenia monitoringu}

Artykuł 33 Konwencji szczegółowo opisuje, w jaki sposób powinno przebiegać wdrażanie Konwencji i jego monitoring w państwach, które ratyfikowały dokument.

Obowiązki państwa wynikające bezpośrednio z omawianego artykułu obejmują:

- ustanowienie punktu kontaktowego (focal point) lub punktów kontaktowych w obrębie struktur rządowych,

- ustanowienie mechanizmu koordynacji (coordination mechanism) w ramach rządu w celu ułatwienia działań związanych $\mathrm{z}$ wdrażaniem w różnych sektorach i na różnych poziomach,

- ustanowienie niezależnej struktury (independent framework), której zadaniem będzie popieranie, ochrona i monitoring wdrażania Konwencji,

- włączenie organizacji zrzeszających osoby z niepełnosprawnościami i działających na ich rzecz w proces monitoringu Konwencji.

Dla porządku warto wspomnieć, że w Polsce punkt kontaktowy ustanowiony został w Biurze Pełnomocnika Rządu ds. Osób Niepełnosprawnych, a jako niezależna struktura pilnująca wdrażania KPON i monitorująca dostęp osób z niepełnosprawnościami do przysługujących im praw wyznaczony został Rzecznik Praw Obywatelskich. Funkcjonowanie tych mechanizmów ma niewątpliwie istotny wpływ na stan wdrożenia KPON w Polsce, jednak ich szczegółowa analiza nie jest przedmiotem niniejszego tekstu.

Jak wskazuje literatura przedmiotu (Stein, 2007), efektywny mechanizm monitorowania KPON jest ważnym warunkiem skutecznego jej wdrażania. Monitoring powinien być realizowany przy aktywnym udziale społeczeństwa obywatelskiego, w tym przede wszystkim przy włączeniu organizacji osób z niepełnosprawnościami (DPO’s) i organizacji działających na ich rzecz - kluczowym czynnikiem dobrze przeprowadzonego monitoringu wdrażania KPON jest udział w tym procesie osób niepełnosprawnych. Zapisane w Konwencji podejście „nic o nas bez nas” stanowi jeden z największych jej dorobków w kontekście innych traktatów o prawach człowieka.

Warto podkreślić, że zasada „nic o nas bez nas” rozpowszechniona została przez aktywistów na rzecz praw osób z niepełnosprawnościami na początku lat 90. XX w. Dziś jest to szeroko rozpowszechnione motto ruchu na rzecz praw tej grupy na całym świecie, nawołujące do uwzględnienia aktywnej roli osób z niepełnosprawnościami w sprawach, które ich dotyczą zarówno na poziomie indywidualnych decyzji, jak i stanowienia prawa czy wypracowywania rozwiązań systemowych (Albrecht, 2006). O ile sama zasada nie budzi wątpliwości, o tyle jej praktyczne implikacje nie są już takie 
oczywiste. Jak zauważa T. Shakespeare, doświadczenie niepełnosprawności oznacza dla każdej osoby coś innego, przez co polityczna tożsamość ruchu, choć niezwykle silna, jest jednocześnie wewnętrznie sprzeczna (Shakespeare, 2014). W tym sensie, o ile motto to na praktycznym poziomie może być rozumiane podobnie (szeroka i włączająca partycypacja), o tyle nieoczywiste jest, kim są „my”, którzy mają się włączenia domagać.

W ostatnim czasie pełna realizacja zasady „nic o nas bez nas” stała się przedmiotem szczególnego zainteresowania Komitetu ONZ ds. praw osób z niepełnosprawnościami, który przygotował komentarz generalny na temat udziału osób z niepełnosprawnościami w monitoringu wdrażania KPON. Możemy w nim przeczytać, że na całym świecie, z nielicznymi wyjątkami, osoby z niepełnosprawnościami wciąż są często wykluczone $\mathrm{z}$ uczestnictwa w procesach decyzyjnych w sprawach, które dotyczą ich samych, a polityka publiczna wobec osób z niepełnosprawnościami w poszczególnych krajach tworzona jest bez ich faktycznego udziału (ONZ, 2018). Prawo i rozwiązania dotyczące niepełnosprawności opracowywane są w konsultacji z ekspertami, akademikami lub przedstawicielami organizacji świadczących konkretne usługi na rzecz osób z niepełnosprawnościami (tzw. organizacje typu service providers). Szczególnie pomijane są środowiska skupiające osoby zagrożone zjawiskiem dyskryminacji wielokrotnej, takie jak niepełnosprawne kobiety, osoby starsze, migranci i uchodźcy, mieszkańcy wsi czy osoby niepełnosprawne o innej niż heteroseksualna orientacji.

Jak zauważają eksperci ONZ w przedstawionym dokumencie, kluczowe dla zmiany tego stanu rzeczy jest zrozumienie, kto w świetle KPON jest uprawniony do reprezentowania osób z niepełnosprawnościami i ustanowienia wyraźnych mechanizmów włączania tych organizacji w procesy podejmowania decyzji. Wskazują oni następujące typy organizacji:

- organizacje zrzeszające osoby z niepełnosprawnościami (tzw. DPO’s - disabled person organisations/OPD's - organisation of person with disabilities $\mathrm{z}$ reguły zrzeszające osoby z jedną konkretną niepełnosprawnością),

- organizacje parasolowe zrzeszające organizacje typu DPO's/OPD’s,

- organizacje osób z różnymi niepełnosprawnościami (cross-disability organisations),

- organizacje rodziców dzieci z niepełnosprawnościami,

- organizacje niepełnosprawnych kobiet.

Wyraźne jest też rozróżnienie pomiędzy organizacjami osób z niepełnosprawnościami a tymi, które działają na ich rzecz. Te drugie to w szczególności organizacje typu service providers - podmioty świadczące konkretne usługi, które, zdaniem członków Komitetu, często przejmują rolę organizacji rzeczniczych. W praktyce jednak organizacje usługowe kierują się przede wszystkim własnym interesem rozumianym jako zysk, a rzecznictwo na rzecz KPON wykorzystują jako narzędzie zwiększające skuteczność swoich działań. 
W omawianym komentarzu generalnym zauważono także, że w procesie włączania osób z niepełnosprawnościami i osób je zrzeszających w działania na rzecz monitoringu wdrażania Konwencji kluczowe jest uwzględnianie przesłanek intersekcjonalnych, takich jak płeć, wiek, orientacja seksualna, miejsce zamieszkania czy przynależność etniczna.

\section{Udział osób z niepełnosprawnościami w monitoringu wdrażania Konwencji w Polsce}

W Polsce, jak zresztą na świecie, osoby z niepełnosprawnościami to bardzo zróżnicowana i niejednorodna grupa. O ile pełne wdrożenie Konwencji w Polsce może być widziane jako łącząca wszystkich idea, o tyle potrzeby poszczególnych grup osób z niepełnosprawnościami są bardzo różne. Trudno zatem mówić o budowie jednorodnego ruchu.

Od momentu ratyfikacji Konwencji przez Polskę, a nawet przed oficjalnym podpisaniem dokumentu, organizacje pozarządowe zrzeszające osoby z niepełnosprawnościami i działające na ich rzecz prowadziły jednak aktywne działania promujące ideę Konwencji w Polsce i monitorujące proces jej wdrażania.

Wśród kluczowych inicjatyw warto przede wszystkim wymienić opracowanie Społecznego Raportu Alternatywnego, organizację Kongresu Osób z Niepełnosprawnościami i projekty monitoringowe prowadzone ze środków Europejskiego Funduszu Społecznego.

Społeczny Raport Alternatywny (SRA) opisuje stan wdrożenia 33 artykułów Konwencji. Został napisany przez 20 autorów, skonsultowany i uzupełniony przez prawie 250 osób. W SRA sformułowano 19 postulatów odnoszących się zarówno do poszczególnych artykułów (m.in. preferowanie edukacji włączającej, otwartego rynku pracy i rozszerzenie oferty usług publicznych), jak i całego procesu wdrażania Konwencji (m.in. podpisanie protokołu fakultatywnego i usunięcie błędów w tłumaczeniu KPON).

Dokument, a co za tym idzie postulaty w nim sformułowane, został poparty przez kilkadziesiąt organizacji (zarówno organizacji zrzeszających osoby z niepełnosprawnościami, jak i organizacji usługowych, tzw. service-providers). Jak można przeczytać we wstępie do opracowania, w trakcie przygotowania raportu odbyło się 12 spotkań rady projektu, 10 paneli eksperckich, 5 spotkań konsultacyjnych (Łódź, Warszawa, Gdynia, Wrocław, Kraków) oraz konferencja podsumowująca.

Warto zauważyć, że mimo tak rozbudowanego procesu tworzenia i konsultowania dokumentu nie została $\mathrm{w}$ nim opisana metodologia prowadzenia badania 
monitoringowego (metody, etapy, sposób prowadzenia analizy). Brakuje także informacji o tym, w jakim zakresie $\mathrm{w}$ badaniu wzięły udział osoby $\mathrm{z}$ różnymi niepełnosprawnościami, znajdujące się w różnej sytuacji ekonomiczno-społecznej (kobiety, osoby starsze, niepełnosprawni mieszkańcy wsi, osoby w różnej sytuacji ekonomicznej). Duża liczba konsultacji społecznych, szeroka grupa organizacji, które podpisały się pod raportem i liczna grupa autorów składająca się także z wielu osób z niepełnosprawnościami, a także osób wspierających osoby z niepełnosprawnościami w codziennym życiu, sprawia, że raport może być uznany za głos środowiska, a jego opracowanie zgodne jest z zasadą „nic o nas bez nas”.

Raport doczekał się aktualizacji - na początku 2018 r. grupa ekspertów związanych ze środowiskiem osób niepełnosprawnych zgłosiła swoje uwagi dotyczące wdrażania przez Polskę Konwencji do Komitetu ONZ ds. Osób Niepełnosprawnych. W przypadku aktualizacji trudno jest mówić o szerokiej i włączającej formule jej opracowywania - dokument przygotowany został w wąskim gronie ekspertów, a konsultacje przeprowadzono $\mathrm{w}$ formie elektronicznej poprzez umieszczenie dokumentu na stronie z prośbą o wysłanie ewentualnych komentarzy.

Wart odnotowania jest także fakt, że środowisko osób i organizacji współtworzących Społeczny Raport Alternatywny od czterech lat organizuje Kongres Osób z Niepełnosprawnościami, który bezpośrednio odnosi się w swoich celach do wdrażania w Polsce Konwencji. Do tej pory odbyły się trzy takie kongresy (w październiku tego roku planowany jest czwarty), w każdym $\mathrm{z}$ nich wzięło udział kilkaset osób niepełnosprawnych z całej Polski. Pierwszy z kongresów związany był bezpośrednio z prezentacją postulatów Społecznego Raportu, drugi zaś skupiał się na wybranych zagadnieniach związanych $\mathrm{z}$ wdrażaniem Konwencji (prawa kobiet $\mathrm{z}$ niepełnosprawnościami, niezależne życie i ubezwłasnowolnienie, aktywizacja zawodowa, selfadwokatura). W trakcie trzeciego kongresu środowisko osób z niepełnosprawnościami i organizacji działających na ich rzecz zaprezentowało pod hasłem „Za niezależnym życiem” założenia do nowego systemu wsparcia osób z niepełnosprawnościami, w których zapisy Konwencji przełożone zostały na propozycję konkretnych działań o charakterze systemowym. Sam Kongres nie jest bezpośrednio związany z działaniami monitoringowymi, ale stanowi platformę wzmocnienia postulatów związanych z lepszym wdrożeniem Konwencji w Polsce i umożliwia budowanie potencjału rzeczniczego osób z niepełnosprawnością i organizacji je reprezentujących. Warto jednak odnotować, że „siłę napędową” Kongresu stanowią duże organizacje o ogólnopolskim zasięgu działania i często uzależnione od pieniędzy publicznych. Taki stan rzeczy ma swoje konsekwencje - dominująca rola dużych graczy, którzy na co dzień świadczą konkretne usługi, a osoby z niepełnosprawnościami traktują w kategoriach klientów czy beneficjentów, utrudnia faktyczne włączanie nowych osób z niepełnosprawnościami w ruch kongresowy. 
Kolejnym dużym działaniem monitoringowym są projekty finansowane ze środków Unii Europejskiej w ramach Programu Operacyjnego Wiedza Edukacja Rozwój (POWER 2.6 Wysoka jakość polityk publicznych na rzecz osób niepełnosprawnych). Celem projektów jest monitoring wdrażania Konwencji ONZ o prawach osób niepełnosprawnych w każdym województwie (16 projektów, w ramach których ma być prowadzony monitoring samorządów), a także w wybranych ministerstwach i jednostkach administracji centralnej.

Projekty te prowadzone są zgodnie z określoną przez Ministerstwo Rodziny, Pracy i Polityki Społecznej metodologią i mają być zakończone konkretnymi rekomendacjami. Zgodnie z narzuconymi wytycznymi projekty muszą być realizowane przez organizacje pozarządowe (bez wskazania kluczowej roli organizacji zrzeszającej osoby z niepełnosprawnościami), koncentrować się na określonych obszarach (m.in. edukacja, praca, usługi wspierające, pomoc społeczna) oraz zakończyć się rekomendacjami, które pozwolą na lepsze wdrożenie Konwencji zarówno na poziomie samorządowym, jak i administracji centralnej.

Jednocześnie wytyczne konkursowe skonstruowane są w taki sposób, że projekty możliwe są do zrealizowania przy minimalnym udziale osób z niepełnosprawnościami, a tym samym nie spełniają wskazywanej przez ONZ zasady „nic o nas bez nas". W wytycznych konkursowych wskazano, że w projekcie musi pracować jedna osoba z niepełnosprawnością. W praktyce oznacza to, że możliwe jest zrealizowanie monitoringu bez ich faktycznego udziału. Dodatkowo formalne wymagania dotyczące realizacji projektów unijnych sprawiają, że projekty te mogą być realizowane właściwie wyłącznie przez duże, dysponujące odpowiednimi zasobami organizacje. Nie ma w tym nic złego, bo realizacja takiego przedsięwzięcia faktycznie wymaga dużych zasobów. Konsekwencje są jednak takie, że w działania nie są zaangażowane organizacje małe i prowadzone faktycznie przez osoby z niepełnosprawnościami.

Na marginesie warto odnotować, że określona przez Ministerstwo Rodziny, Pracy i Polityki Społecznej metodologia prowadzenia monitoringu nie obejmuje kompleksowo wszystkich artykułów Konwencji, pomijając m.in. tak ważny obszar związany z funkcjonowaniem każdej osoby jak zdrowie. W metodologii, mimo ściśle określonej listy pytań, nie pojawiają się zagadnienia związane z sytuacją niepełnosprawnych kobiet czy osób starszych. Trudno też znaleźć pytania wskazujące na konieczność zbadania sytuacji osób z różnymi niepełnosprawnościami. W konsekwencji dane pozyskane w monitoringu nie dotykają rzeczywistych problemów poszczególnych grup, a jedynie sygnalizują kwestie o charakterze ogólniejszym (np. dostępność cyfrowa czy architektoniczna).

Kluczowym wydarzeniem wieńczącym działania monitoringowe jest sprawozdanie Polski przed Komitetem Praw Osób Niepełnosprawnych ONZ w Genewie. Strona społeczna ma możliwość uczestnictwa w procesie sprawozdawczym na wszystkich 
jego etapach - złożenia raportu alternatywnego (tzw. shadow report), odniesienia się do pytań zadanych przez Komitet rządowi (tzw. list of issues), a także uczestnictwa w samym posiedzeniu sprawozdawczym. Efektem całego procesu są rekomendacje, które Komitet ONZ kieruje do polskiego rządu. Uczestnictwo przedstawicieli społeczeństwa obywatelskiego jest tym bardziej kluczowe, że możliwość przedstawienia faktycznej sytuacji osób z niepełnosprawnościami w Polsce to także możliwość wpływu na kształt i kierunek wypracowanych przez Komitet rekomendacji. Te zaś mogą być wykorzystane do dalszych działań rzeczniczych i wywierania wpływu na rząd w kwestii poprawy sytuacji osób z niepełnosprawnościami w poszczególnych obszarach.

Na początku września 2018 r. w Genewie odbyło się główne posiedzenie sprawozdawcze dotyczące Polski. Reprezentacja strony społecznej liczyła pięć osób, głównie działających oddolnie aktywistów niezwiązanych z żadnym z największych stowarzyszeń czy fundacji. Warto zaznaczyć, że żadna z dużych organizacji, mimo prowadzenia aktywnych działań na rzecz KPON na poziomie krajowym, nie wysłała do Genewy swojego przedstawiciela.

Oprócz opisanych powyżej prac o dużym, często ogólnopolskim, zasięgu osoby z niepełnosprawnościami niejednokrotnie podejmują wysiłki na rzecz wdrożenia KPON i pełnej realizacji określonych w niej praw poprzez działania oddolne - powoływanie lokalnych lub skupionych na konkretnym temacie organizacji, działania akcyjne itd. Jako przykład można podać działalność krakowskiej feministycznej organizacji kobiet z niepełnosprawnościami Strefa Wenus z Milo lub warszawskiej fundacji Kulawa Warszawa, której aktywistki działają zarówno na rzecz dostępności, jak i niedyskryminacji osób z niepełnosprawnościami.

Obraz działań monitoringowych wyłaniający się z powyższego opisu nie jest jednoznaczny - z jednej strony widać aktywne działania organizacji pozarządowych, z drugiej zaś dominująca jest rola dużych, uzależnionych od środków publicznych graczy, niejednokrotnie marginalizujących znaczenie innych podmiotów.

\section{Główne problemy związane z włączaniem osób z niepełnosprawnościami w działania na rzecz wdrażania Konwencji}

Przeprowadzona powyżej analiza, a także osobiste doświadczenia autorki artykułu związane $z$ bezpośrednią realizacją działań monitoringowych na rzecz wdrażania KPON, pokazują, że włączenie osób z różnymi niepełnosprawnościami wciąż napotyka wiele barier i problemów. W tak krótkim artykule nie sposób dogłębnie przeanalizować wszystkie, z pewnością jednak warto wskazać kilka czynników. 
Pierwszym z nich jest duża i dominująca rola organizacji o charakterze usługowym, często uzależnionych od środków publicznych.

Wśród głównych organizacji pozarządowych działających na rzecz osób z niepełnosprawnościami w Polsce należy wymienić przede wszystkim Polskie Stowarzyszenie na rzecz Osób z Niepełnosprawnością Intelektualną (PSONI), Polski Związek Głuchych (PZG), Polski Związek Niewidomych (PZN), Fundację Aktywizacja, Fundację Aktywnej Rehabilitacji, Stowarzyszenie Przyjaciół Integracji i Fundację Instytut Rozwoju Regionalnego. Organizacje te można podzielić na kilka kategorii, które nie dają się łatwo zamknąć $\mathrm{w}$ ramach proponowanych przez wspomniany komentarz generalny ONZ.

Oprócz organizacji typowo usługowych (Fundacja Aktywizacja) działają organizacje łączące funkcje usługowe i jednocześnie zrzeszające osoby z różnymi niepełnosprawnościami lub ich opiekunów (PSONI, PZG). Dodatkowo, nie wszystkie z dużych organizacji traktują KPON jako ważny drogowskaz prowadzonych działań i prezentują anachroniczny sposób rozumienia niepełnosprawności oraz praw osób niepełnosprawnych (PZN). Jednocześnie w Polsce praktycznie nie ma instytucji parasolowej zrzeszającej organizacje osób z niepełnosprawnościami. Polskie Forum Osób Niepełnosprawnych, które w założeniu miało odgrywać taką rolę, faktycznie nie funkcjonuje. Dodatkową konsekwencją braku organizacji parasolowej jest fakt, że Polska jako jedyne państwo w UE nie ma aktywnej reprezentacji w Europejskim Forum Niepełnosprawności (EDF).

Organizacje pozarządowe działające na rzecz osób z niepełnosprawnościami i je zrzeszające, a także organizacje usługowe, w warunkach polskich bardzo często uzależnione są od środków publicznych. Fakt ten ma bezpośrednie przełożenie na prowadzone działania monitoringowe. Lęk o utratę pieniędzy, co w konsekwencji doprowadziłoby do konieczności zmniejszenia zakresu prowadzonych działań i zagroziło stabilności funkcjonowania, powoduje dużą ostrożność organizacji przy zajmowaniu stanowiska ws. przestrzegania praw osób niepełnosprawnych w Polsce. Przykładem może być stosunek dużych organizacji do protestu osób niepełnosprawnych i ich opiekunów wiosną 2018 r. Duże organizacje nie zdecydowały się na otwarte poparcie protestu, szukały wyważonych form wyrażenia swojego zdania, które uwzględniałoby także perspektywę rządową. W konsekwencji stały się wielkimi nieobecnymi wiosennych wydarzeń. Jednocześnie warto wyraźnie podkreślić, że usługi prowadzone przez duże organizacje na rzecz osób z niepełnosprawnościami często nie tylko wspierają, ale wręcz wyręczają państwo $\mathrm{w}$ działaniach na rzecz tej grupy (dobrym przykładem jest tu choćby rola Fundacji Aktywizacja w działaniach na rzecz zatrudnienia osób z niepełnosprawnościami). 
Na poziomie symbolicznym konflikt ten widoczny był także w czasie wspomnianego posiedzenia sprawozdawczego w Genewie, gdzie wystąpienie po stronie społecznej oznaczało bezpośrednią konfrontację ze stroną rządową. Duże organizacje nie wysłały swojego przedstawicielstwa, usunęły się na drugi plan, oddając pole oddolnym aktywistom.

Mimo oczywistego konfliktu interesów, który utrudnia dużym organizacjom usługowym konsekwentne i bezkompromisowe działania na rzecz wdrażania KPON, to właśnie one mają największą siłę przebicia i często reprezentują środowisko osób $\mathrm{z}$ niepełnosprawnościami w kontakcie $\mathrm{z}$ rządem (uczestnictwo w konsultacjach, konferencjach, komisjach sejmowych i senackich). Pomagają w tym ich zasoby czasowe i kadrowe.

Warto wspomnieć również o dużym udziale pełnosprawnych ekspertów i działaczy w pracach monitoringowych i rzeczniczych związanych z wdrażaniem KPON.

Pełnosprawni działacze, prezesi organizacji i akademicy, występują w Polsce często jako eksperci w sprawie osób z niepełnosprawnościami lub wręcz jako reprezentanci środowiska. O ile wsparcie sojusznicze jest bardzo ważne dla całego procesu monitoringu i de facto wspomaga wdrażanie KPON, o tyle mocne wchodzenie $\mathrm{w}$ role reprezentujące zabiera przestrzeń niepełnosprawnym osobom i utrudnia ich włączenie w myśl zasady „nic o nas bez nas”. Przykładem mogą być pełnosprawni eksperci wypowiadający się w imieniu środowiska na temat zatrudnienia osób niepełnosprawnych.

Istotnym problemem jest bardzo słabo słyszalny, praktycznie nieobecny w debacie głos osób w szczególnie trudnej sytuacji, zagrożonych dyskryminacją wielokrotną (brak podejścia intersekcjonalnego).

Komentarz generalny ONZ zwraca szczególną uwagę na uwzględnienie intersekcjonalnego charakteru środowiska osób niepełnosprawnych oraz upewnienie się, że osoby narażone na dyskryminację wielokrotną i będące w szczególnie trudnej sytuacji otrzymają możliwość włączenia się w debaty i działania, a ich głos zostanie usłyszany. W Polsce takie podejście na razie jest w powijakach - o ile słyszalny zaczyna być głos kobiet z niepełnosprawnościami, o tyle wciąż są grupy, których perspektywa praktycznie nie jest uwzględniana (mieszkańcy wsi, osoby starsze, osoby z niepełnosprawnościami sprzężonymi, migranci czy osoby LGBT). W konsekwencji problemy tych grup pozostają praktycznie niezauważone, tworząc złudne poczucie, że tych przeciwności losu po prostu nie ma.

Przytoczona powyżej lista nie wyczerpuje w pełni przyczyn niewystarczającego włączenia osób z niepełnosprawnościami w działania na rzecz monitoringu wdrażania KPON w Polsce, a jedynie zarysowuje specyficzne dla środowiska osób niepełnosprawnych kwestie. Do wymienionych przyczyn warto dodać przynajmniej 
niską świadomość swoich praw wśród samych osób z niepełnosprawnościami czy słabą kondycję społeczeństwa obywatelskiego w Polsce w ogóle.

$$
* * *
$$

Mimo zidentyfikowanych problemów i barier w Polsce prowadzone są aktywnie działania na rzecz monitoringu wdrażania Konwencji ONZ o prawach osób niepełnosprawnych. Działania te inicjowane są w dużej mierze przez duże organizacje pozarządowe i - niejednokrotnie pełnosprawnych - ekspertów. Do prowadzenia monitoringów wykorzystane zostały także środki unijne, co zwiększyło zasięg prowadzonych działań, ale nie przyczyniło się do większego włączenia osób z niepełnosprawnościami $\mathrm{w}$ ten proces.

Dominacja organizacji o charakterze usługowym utrudnia budowanie ruchu na rzecz monitoringu i wdrażania Konwencji, ponieważ osoby z niepełnosprawnościami w tych organizacjach są często biernymi odbiorcami działań, a nie aktywnymi członkami angażującymi się w pracę na rzecz praw osób z niepełnosprawnościami. $Z$ drugiej jednak strony nie da się nie zauważyć faktu, że to te organizacje są motorem wielu działań i na bieżąco nadzorują sytuację osób z niepełnosprawnościami w Polsce. Przykładem tego jest opracowanie Społecznego Raportu Alternatywnego czy też organizacja Kongresu Osób z Niepełnosprawnościami. Kluczową barierą utrudniającą monitoring jest uzależnienie od środków publicznych i uzasadniona obawa o ich utratę w przypadku aktywnego prowadzenia działań niezgodnych z linią proponowaną przez rząd.

Jednocześnie dominacja dużych graczy utrudnia dojście do głosu małym, oddolnym organizacjom zrzeszającym osoby z niepełnosprawnościami, ich rodziców i opiekunów. Bardzo rzadko słyszalny jest głos tych osób niepełnosprawnych, które znajdują się w szczególnie trudnej sytuacji i narażone są na dyskryminację wielokrotną. Brak uwzględnienia perspektywy intersekcjonalnej w prowadzonych działaniach monitoringowych sprawia, że część problemów środowiska nie jest w ogóle widoczna, przez co nie jest możliwe prowadzenie działań mających na celu ich rozwiązanie.

Komentarz generalny do artykułu 33 KPON wymaga od środowiska osób z niepełnosprawnościami i organizacji działających na ich rzecz krytycznego spojrzenia na sposób realizowania działań monitoringowych. Kluczowe dla tego procesu jest określenie roli organizacji usługowych, a także pełniejsze włączenie tych osób z niepełnosprawnościami, które znajdują się w szczególnie trudnej sytuacji z racji ich cech i sytuacji życiowej. 


\section{Bibliografia}

Albrecht, G.L. (2006). Encyclopedia of Disability. London: Sage Publications.

Barnes, C., Mercer, G. (2014). Niepetnosprawność. Warszawa: Sic!.

Degener, T. (2016). Disability in a Human Rights Context. Laws 5(3).

De Beco, G. (2011). Article 33(2) of the UN Convention on the Rights of Persons with Disabilities: Another Role for National Human Rights Institutions?. Netherlands Quarterly of Human Rights.

Głąb, Z., Kurowski, K. (red.) (2018). Answers to the UN Committee on the Rights of Persons with Disabilities List of Issues within the Evaluation of the Polish Report on the Implementation of the UN Convention on the Rights of Persons with Disabilities, https://tbinternet.ohchr.org/_layouts/ treatybodyexternal/SessionDetails1.aspx?SessionID=1206\&Lang=en (dostęp: 19.09.2018).

Kubicki, P. (2017). Polityka publiczna wobec osób z niepełnosprawnościami. Warszawa: Oficyna Wydawnicza SGH.

Ministerstwo Rodziny Pracy i Polityki Społecznej (2016). Metodologia prowadzenia monitoringu działań jednostek administracji pod kątem realizacji praw osób z niepetnosprawnościami zawierajaca minimalne wymogi dla przeprowadzenia tego monitoringu, $w$ tym projekt narzędzia do wykorzystania przez projektodawców przy prowadzeniu ww. monitoringu, https://efs.mrpips.gov.pl/skorzystaj/nabory/monitoring-dzialan-jednostek-administracji-rzadowej-i-samorzadowej-pod-katem-realizacji-praw-osob-z-niepelno-sprawnosciami (dostęp 16.09.2018).

Office of the High Commissioner for Human Rights (2007). From Exclusion to Equality. Realizing the rights of persons with disabilities. Handbook for Parliamentarians on the Convention on the Rights of Persons with Disabilities and its Optional Protocol. Geneva.

ONZ (2006). Konwencja ONZ o prawach osób niepetnosprawnych, http://prawo.sejm.gov.pl/ isap.nsf/DocDetails.xsp?id=WDU20120001169 (dostęp: 13.09.2018).

ONZ (2010). Monitoring the Convention on the Rights of Persons with Disabilities. Guidance for Human Right Monitors. New York and Geneva.

ONZ (2018). General comment on article 4.3 and 33.3 of the convention on the participation with persons with disabilities in the implementation and monitoring of the Convention, https:// www.ohchr.org/EN/HRBodies/CRPD/Pages/GC.aspx (dostęp: 17.09.2018).

Shakespeare, T. (2014). Disability rights and wrongs revisited. New York: Rotledge.

Stein, M.A. (2007). Monitoring the Convention on the rights of persons with disabilities: innovations, lost opportunities, and future potentials. Cambridge: Harvard Law School Project on Disability.

Zadrożny, J. (red.) (2015). Społeczny Raport Alternatywny z realizacji Konwencji o prawach osób z niepetnosprawnościami w Polsce (Alternative Report on the Implementation of the UN Convention on the Rights of Persons with Disabilities). Warszawa. 